\title{
Kravchenko 0. \\ DEVELOPMENT OF MEDICAL DIAGNOSTIC DECISION SUPPORT SYSTEMS AND THEIR ECONOMIC EFFICIENCY
}

Об’єктом дослідження є діагностичні системи підтримки ухвалення рішень (СПУР). Одним з найбільш проблемних місць в медичних діагностичних системах є формування бази знань на основі правил експерта, за якою надається рекомендація щодо хвороби. Проведено дослідження методів проектування медичних діагностичних систем. Розглянуто методи застосування потенціалу штучного інтелекту в медицині у вигляді формування нечітких правил або проведення діагностики на основі байєсівських мереж. Розглянуто інтелектуальні обчислювальні засоби у вигляді експертних систем на основі правил та нечіткої логіки, що застосовуються до нейронних мереж та генетичні алгоритми, що виконуються в медичній діагностиці.

Для розробки системи підтримки ухвалення рішень лікаря-педіатра було обрано метод формування бази знань на основі логічних правил «якщо..., то...». Використання даного методу дозволяє сформувати початкові умови вхідних даних до системи, та прискорити їх обробку в базі знань. Хоча при цьому база знань є досить громіздкою, але це не зменшує продуктивність використання системи.

В процесі дослідження описано розробку медичної діагностичної системи підтримки ухвалення рішень лікарем-педіатром за етапами проектування. Застосування даної системи дозволяє автоматизувати процес документообігу для лікаря-педіатра та пришвидиити етап попереднього оцінювання стану пацієнта.

Вбудований модуль електронного довідника педіатра не тільки автоматизує процес документообігу, що зменшує час роботи лікаря з паперами, а й дозволяє отримувати повну інформацію про пацієнта.

Виконано розрахунок економічної ефективності від впровадження СПУР лікарем-педіатром. Розрахована вартість системи має окупитися протягом 1 року.

Перспектива додавання модулів до системи за окремими хворобами та формування електронної картки з моменту народження з перспективою передачі даних до системи для дорослих є перевагами перед аналогами даного програмного продукту.

ключеві слова: медичні системи підтримки ухвалення рішень, розробка програмного забезпечення, економічна ефективність.

\section{Introduction}

The application of information technologies in all spheres of human life implies both the development of software and its implementation in all sectors of the economy, social sphere, medical institutions, etc. Present in Ukraine requires to move quickly towards the development and application of applied medical programs affecting the work of medical personnel, increasing its efficiency and increasing economic benefits.

The exchange of information is crucial for providing assistance at all levels of the medical care system - the patient, doctors, the organization of health care and the political and economic conditions in general [1].

The development of medical information systems and decision support systems is an urgent task. Analysis of the use of computer equipment in medical institutions shows that it is usually used for processing textual information, ensuring the process of document circulation and maintaining databases [2]. In part, computers are used to support the operation of diagnostic and therapeutic devices [3].

The creation of decision support systems (DSS) by a specialized doctor meets the requirements. Establishing a preliminary diagnosis is an important stage in the treat- ment of the patient. The creation of a diagnostic medical decision support system will ensure the process of timely and reliable diagnosis of the patient to choose the right treatment. This system aims to connect the knowledge of the doctor, long-term knowledge and research in medicine by the type of disease with information technology.

\section{The object of research and its technological audit}

The object of research is the diagnostic decision support system.

The study is carried out on the example of doctorpediatrician DSS. The system for diagnosis of childhood diseases should contain a database of medical data, a knowledge base based on expert rules and formulate recommendations to the pediatrician to assist in making preliminary decisions. Also, this system will be a module of an electronic pediatrician's directory that will contain information about infants, their vaccinations and will allow them to form their medical record.

One of the most problematic places in the study is the formation of a knowledge base based on expert rules, which provides a recommendation for the disease. 


\section{The aim and objectives of research}

The aim of research is the process of designing and implementing a medical diagnostic decision support system and calculating the cost-effectiveness of its implementation.

To achieve this aim it is necessary:

1. To carry out research on the methods of designing DSS by a pediatrician.

2. To describe the logical links of the nodes of the system at the stage of designing a decision support system for a pediatrician with the help of Case tools.

3. To describe the weighting factors for the rules of the knowledge base of the system that corresponds to the sets of childhood symptoms of disease.

4. To identify the structural diagram of the DSS work by a pediatrician and the main results of the work.

5. To calculate the economic efficiency from the DSS introduction by a pediatrician.

\section{Research of existing solutions of the problem}

Medical information technologies include means of influencing the body with external information factors, a description of the methods and methods of their application, and a process of teaching practical skills. The first is the question of the need to widely introduce proven means and methods of information impact into clinical practice that meet such requirements as safety and ease of use, high therapeutic effectiveness of application [4].

The next important issue is the stimulation and encouragement of the development and creation of new tools and methods of influence on the human body, which correspond to the principles and postulates of information medicine. One of the main ways to solve a number of medical, social and economic problems today is to inform the work of medical personnel [5]

The basic link of informatization is the use in hospitals of modern clinical information systems equipped with decision support mechanisms. However, these systems were not widely used, since scientific and methodological approaches to the creation of clinical information systems have not been developed yet [5].

Work [6] is devoted to the analysis of methods and tools of medical expert systems. Some researchers evaluate their medical expert systems in hospitals, starting with inspectors and receive various parameters, such as accuracy and sensitivity. Using these parameters, they evaluated the effectiveness of their expert systems [7-9]. Accuracy along with other parameters of the expert system depends on the knowledge base, has the appropriate knowledge. It is necessary to worry about acquiring knowledge, the stage in which knowledge is collected [10, 11].

Thus, the indicators of the expert system depend on each of these factors. It is possible to increase the productivity of the expert system by creating a more accurate knowledge base, and very little work with the use of neuro-fuzzy, anisotropic and fuzzy logic in medical diagnostics [12].

The study of methods for designing medical diagnostic systems is an important stage in the development of software for medical systems.

The paper [13] discusses the application of the potential of artificial intelligence in medicine. The diagnosis is presented on the basis of a fuzzy expert system, and approbation is carried out on the example of diagnosing liver diseases.

Effective mechanisms for anamnesis are the establishment of cause-effect relationships between diseases and symptoms. The paper [3] offers a description of a web-based system for the medical diagnosis of sleep based on Bayesian networks. This method allows the expert to interact with the user to establish a probable diagnosis.

Description of the development of the expert system of mobile applications to assist the doctor in the diagnosis, analysis and treatment of hydrocephalus are given in [14]. The paper considers intelligent computing tools in the form of expert systems based on rules and fuzzy logic applied to neural networks and genetic algorithms performed in medical diagnostics.

Based on the research data, the method of forming a set of symptoms for childhood diseases and forming weight coefficients for the knowledge base rules in the form «If .., then ...» was chosen.

\section{Methods of research}

Medical systems are systems of organization and optimization of the activity of a medical institution:

- convenience of work for the personnel;

- control and analysis for the manager.

The systems allow to effectively and conveniently automate all the basic daily operations of document circulation:

- patient registration;

- management of medical records;

- work planning;

- settlements with customers;

- preparation of reports in organizations of various types and scales.

At the stage of creating a conceptual model for describing business activities, business use case models and activity diagrams are used, to describe business objectsbusiness object models and sequence diagrams.

At the stage of creating a logical model of a pediatrician DSS, a description of the system requirements is given in the form of a model and a description of system use cases, and preliminary design is carried out using class diagrams, sequence diagrams and state diagrams.

At the stage of creating a physical model, detailed design is performed using class diagrams, component diagrams, and deployment diagrams. Context Diagram of a pediatrician DSS is built in the BPwin environment (Fig. 1).

The input stream (material or information that is used or transformed by the work to obtain the result) is information about the patient, which is received by the registrar of pediatrician DSS

Management (rules, strategies, procedures or standards that govern the work) is the State Standard of the work of the economy and the legislation of Ukraine.

Exit (material or information that is produced by work) is the electronic medical record of the patient and referral to the doctor is created.

Mechanism (resources that perform work) is the registrar.

IDEF3 diagrams are used to study technological processes. They describe the scenario and the sequence of operations for each process. The result of creating the IDEF3 diagram is shown in Fig. 2.

Pediatrician DSS consists of several interrelated modules (Fig. 3). 


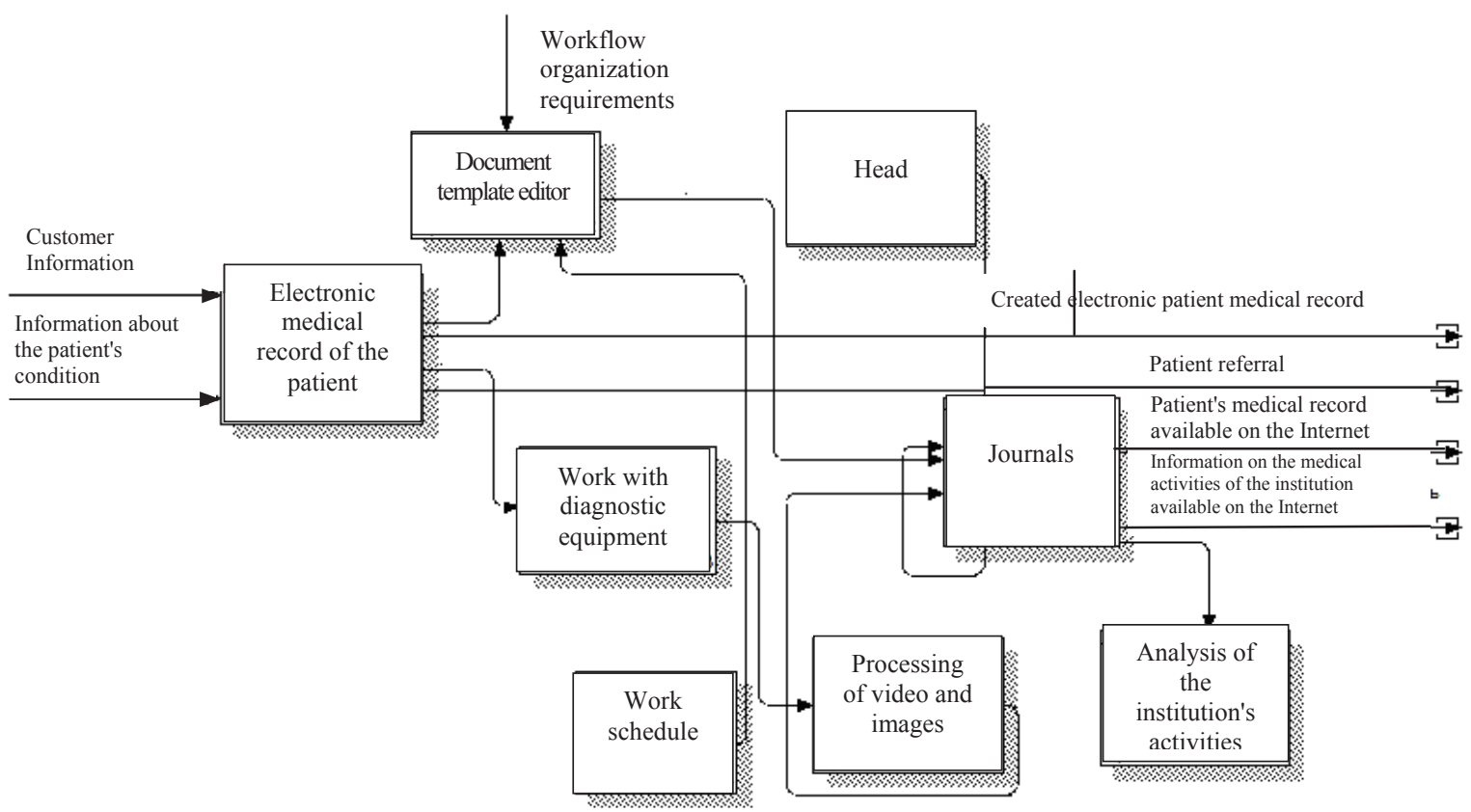

Fig. 1. Functional decomposition of the contextual diagram of the decision support system of a pediatrician in the BPwin environment

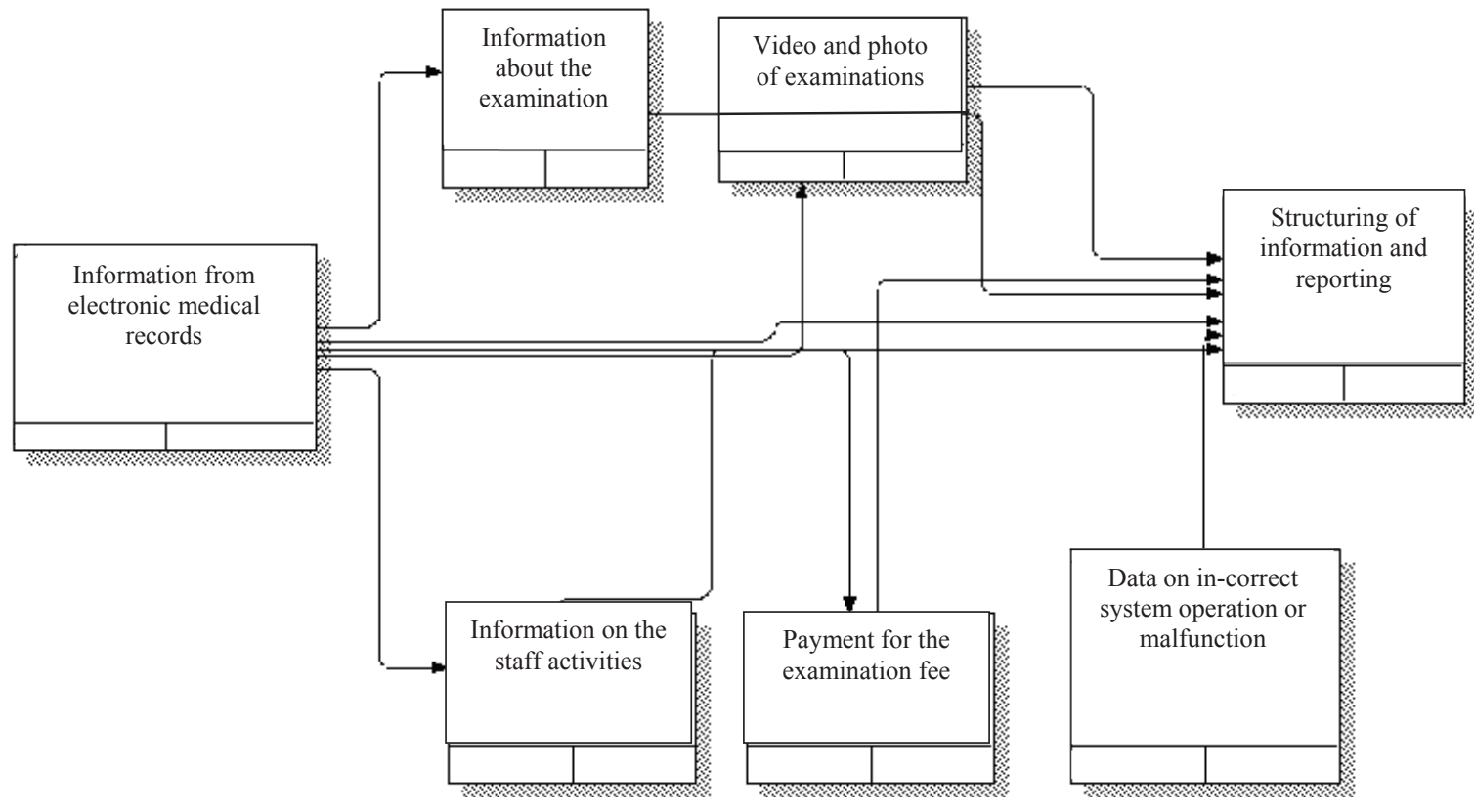

Fig. 2. Creation of an IDEF3 chart

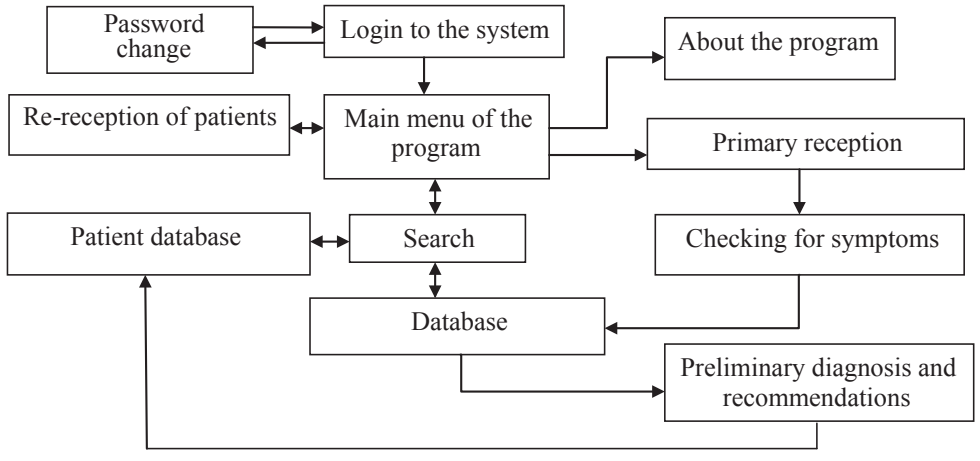

Fig. 3. Structure of the pediatrician decision support system
Based on the medical directories in the process of pediatrician DSS development, let's form a set of rules in the knowledge base, characterizing the disease by symptom.

Fig. 4 presents the task of forming a preliminary diagnosis in the form of a network, where $a_{i}$ - the symptoms obtained from the patient during the survey $(i=\overline{1, n}), b_{j}$ - the symptoms that characterize the disease after expert knowledge $(j=\overline{1, m}), c$ - preliminary diagnosis.

The arcs express the causal relationships between the variables $a_{i}, b_{j}, c_{k}$. 


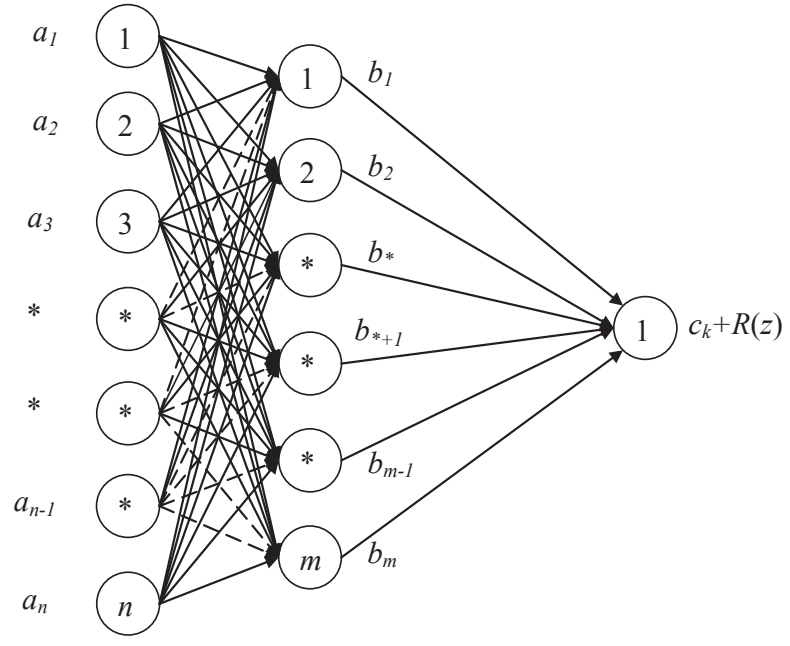

Fig. 4. Presentation of the task of forming a preliminary diagnosis in the form of a network

The processing of diagnostic information that forms the knowledge base in a general way will be described in the form of a general rule «If ..., then ...».

$$
\text { If }\left\{\begin{array}{c}
a_{1}=b_{1} \text { with } p\left(x_{i}\right) \\
\vdots \\
a_{n}=b_{n} \text { with } p\left(x_{n}\right)
\end{array} \text {, then }\left[c_{k} \text { with } \sum_{i=1}^{n} p\left(x_{i}\right)\right]+R(z)\right. \text {, }
$$

where $a_{1} \ldots a_{n}$ - the symptoms when the patient is questioned; $b_{1} \ldots b_{n}$ - the symptoms of the disease, as determined by the expert; $p\left(x_{i}\right)$ - weight coefficients of a symptom received from experts; $c_{k}$ - preliminary diagnosis; $\sum_{i=1}^{n} p\left(x_{i}\right)$ - the total weight of the diagnosis with the weight coefficients of the symptom; $R(z)$ - set of recommendations for conducting laboratory tests that must confirm a preliminary diagnosis.

In each rule, for a corresponding disease, a set of symptoms and weights for their importance for the disease are indicated (Table 1). Coefficients are determined on the basis of knowledge of medical experts.
Table 1

A set of symptoms and weights for the knowledge base of the decision support system of a pediatrician

\begin{tabular}{|c|c|}
\hline Symptom & Weights \\
\hline \multicolumn{2}{|c|}{ Adenoids } \\
\hline Open mouth & 15 \\
\hline Snore & 10 \\
\hline Dyspnea & 7 \\
\hline Cough & 5 \\
\hline \multicolumn{2}{|c|}{ Adenovirus infection } \\
\hline $\begin{array}{c}\text { Preliminary diagnosis - adenoids. To check the diagnosis should be carried } \\
\text { out studies of the oral cavity and nasopharynx with an endoscope }\end{array}$ \\
\hline Runny nose & 10 \\
\hline Cough & 8 \\
\hline Enlarged lymph nodes & 7 \\
\hline Conjunctivitis & 5 \\
\hline
\end{tabular}

Preliminary diagnosis is adenovirus infection. To check the diagnosis should be carried out studies of the oral cavity and nasopharynx with an endoscope. It is also desirable to conduct a laboratory study of blood and ECG (electrocardiogram), CFR procedures (complement fixation reaction) and HIR (haemagglutination inhibition reaction)

\begin{tabular}{|c|c|}
\hline \multicolumn{2}{|c|}{ Angina } \\
\hline Sore throat & 15 \\
\hline Headache & 9 \\
\hline Weakness & 7 \\
\hline Fever & 7 \\
\hline
\end{tabular}

Preliminary diagnosis is angina. To check the diagnosis should be carried out studies of the oral cavity. It is also desirable to conduct a laboratory examination of blood and ECG, the CFR and HIR procedures

Based on the results of diseases, a preliminary diagnosis and recommendations for in-depth medical research are possible.

Let's give examples of combinations of symptoms for several diseases with a possible preliminary diagnosis.

\section{Research results}

6.1. Software implementation of the diagnostic pediatrician D55. Pediatrician DSS is designed to automatically determine a patient's diagnosis based on the selected symptoms and to maintain a physical data record for the child (Fig. 5).

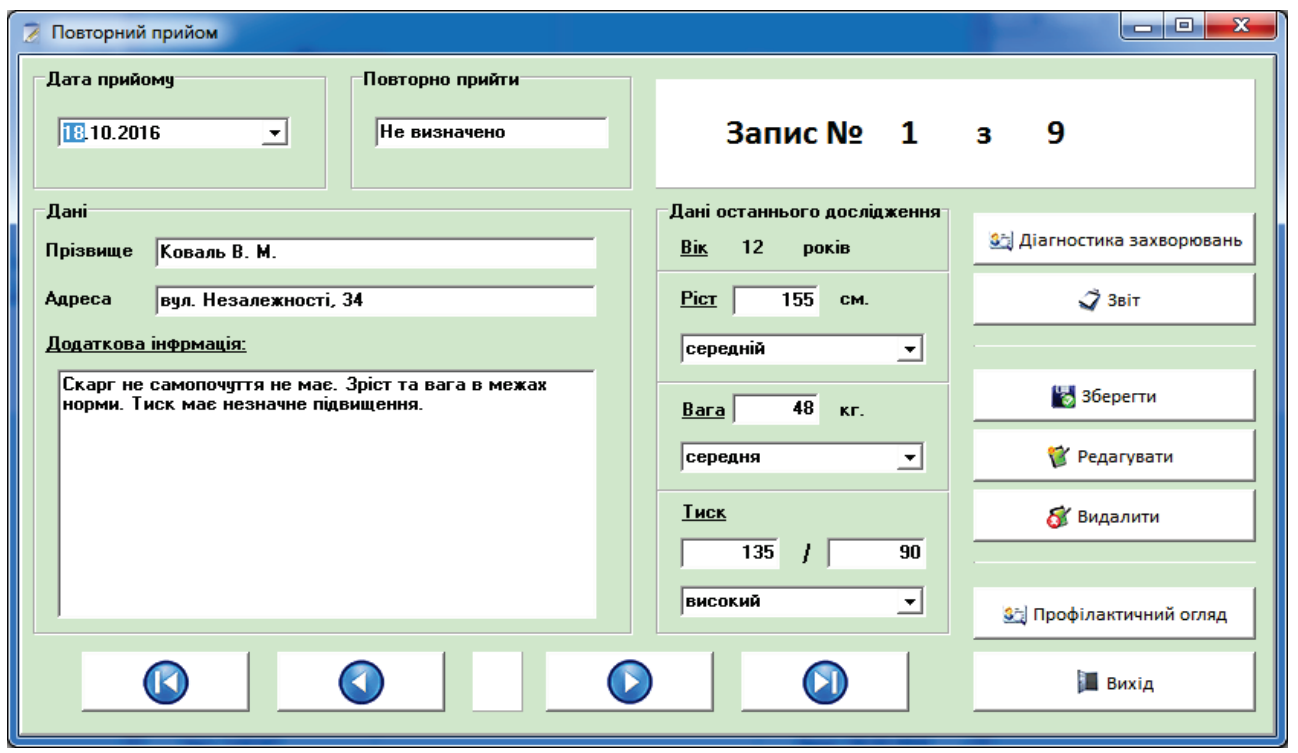

Fig. 5. The patient record window of the pediatrician decision support system 
After filling in the data, the program automatically calculates the patient's age, growth rate, weight and pressure.

With the help of the «Diagnosis» form, the pediatrician marks symptoms during the formation of an anamnesis.

After selecting the existing symptoms, a window opens to view the selected symptoms and diagnoses that coincide with these symptoms. Also, each diagnosis corresponds to a certain assessment, it makes it possible to determine the most probable diagnosis.

After a preliminary interview with the patient pediatrician DSS prepares a preliminary diagnosis in the form of a report and suggests that laboratory tests be performed to confirm a diagnosis (Fig. 6).

\section{REPORT}

Patient's surname V. Koval
\begin{tabular}{|l|l|l|}
\hline Symptoms & Diagnosis & Estimation \\
\hline Cough & Diagnosis & 5 \\
Headache & Adenoids & 13 \\
Conjunctivitis & Adenoid infection & 24 \\
Sore throat & Angina & 6 \\
Sleep disturbance & Anemia & 3 \\
& Heart defects & 14 \\
& Sinusitis & 10 \\
& Diphtheria & 15 \\
& Whooping cough & 7 \\
& Otitis media & 5 \\
& Parotitis & \\
\hline
\end{tabular}

Preliminary diagnosis: angina. To check the diagnosis should be carried out studies of the oral cavity. It is also desirable to conduct a laboratory examination of blood and ECG, the CFR and HIR procedures

Fig. 6. The report window of the pediatrician decision support system

This report will reflect all selected symptoms, diagnoses related to them and assessing these diagnoses. Also, there will be a message about a preliminary diagnosis, which is most likely.

6.2. Calculation of economic efficiency from the pediatrician DSS introduction. Analysis based on the selected assessments and criteria is a complex and intellectuallysaturated process. All costs and benefits should be expressed in money terms and on the basis of the balance sheet figures in order to make an appropriate decision. The most difficult is to calculate the quantitative evaluation of efficiency from the implementation of the software product. To do this, it is necessary to perform a detailed analysis of the actual benefits of the implementation system and to identify the factors that characterize the various directions for obtaining benefits [15, 16].

The annual economic effect from the introduction of a new software product is calculated by the formula:

$$
\begin{aligned}
& \Delta E=\left(\frac{E_{1}}{Q_{1}}-\frac{E_{2}}{Q_{2}}\right) \cdot Q_{2} \text { USD } / \text { year, } \\
& \Delta E=\left(\frac{29900}{2550}-\frac{38452.44}{10200}\right) \cdot 10200=80580 \mathrm{USD} / \text { year, }
\end{aligned}
$$

where $E_{1}$ - operating costs when using an existing software product (or without its use at all), USD/year; $E_{2}$ - operating costs when using a new software product, USD/year; $Q_{1}$ - conditional volume of work performed for a year when using an existing software product or without using it at all (conditional units, number of functions, etc.); $Q_{2}-$ conditional volume of work that is performed for the year when applying a new software product (conditional units, number of functions, etc.).

Calculation of the payback period $T_{0}$ of costs that are used for development can be calculated by the formula:

$$
T_{0}=\frac{B}{\Delta E}=\frac{79385.55}{80580}=0.98 \text { year. }
$$

Since $T_{0}<1-3$ years, new software product is considered to be cost-effective.

Next, let's calculate the capital investment needed to develop each of the proposed options for the software product, as well as the operating costs for each of these options.

The unit cost of a new development $S$ can be calculated by the formula:

$$
S=\frac{B_{n} \cdot K_{n} \cdot 100 \%}{\mathrm{SW} \%} \mathrm{USD}
$$

where $B_{n}-$ the value of a specific direct cost item for a new development that is selected as a basis, USD; $S W-$ specific weight of this item of expenses in the cost of the analogue, \%; $K_{n}$ - coefficient that takes into account the design and technological features of the new development.

The rewards for developers are direct costs, which will be paid from each material carrier with the recorded software product (the so-called value of intellectual property). In addition, it is known that in products of a similar type, the specific weight is $40-45 \%$.

$$
S=\frac{500 \cdot 1.1 \cdot 100 \%}{43 \%}=1279.1 \mathrm{USD} .
$$

The value of capital investments $C$ can be calculated by the formula:

$$
C=B \cdot A \cdot S=1.5 \cdot 2 \cdot 1279.1=3837.3 \mathrm{USD},
$$

where $B$ - coefficient that takes into account the costs of development, acquisition, transportation, installation, commissioning of a new development, etc., $B \approx 1.2-2.0$; $A$ - coefficient that takes into account the projected profit and taxes that the producer must pay, $A \approx 1.7-2.3$; $S$ - cost of new development, calculated in a simplified way, USD.

Operational costs are those costs that ensure the normal operation of a certain technical solution during its operation per year.

The amount of operating costs $E$ for the year can be calculated by the formula:

$$
\begin{aligned}
& E=k \cdot P \cdot \beta=k \cdot A \cdot S \cdot \beta \mathrm{USD} / \text { year, } \\
& E=0.4 \cdot 2 \cdot 1279.1 \cdot 0.2 \mathrm{USD} / \text { year, }
\end{aligned}
$$

where $P$ - price of the implementation of a new development, if it was known or determined earlier, USD/pcs; $k$ - coefficient that takes into account the cost of computing equipment $k=0.4-0.7 ; A-$ coefficient that takes into account the projected profit and taxes that the producer 
must pay, $A \approx 1.7-2.3 ; S-$ cost of new development, calculated in a simplified way, USD; $\beta$ - the proportion of time that an employee spends on servicing a new technical or intellectual development in the total time of his work.

From the introduction of a new software product, the annual economic effect is 80580 USD, all costs will be paid back within 1 year.

\section{SWOT analysis of research results}

Strengths. The strength of the pediatrician decision support system is its structure, which contains a medical data base, a knowledge base based on expert rules and a module for advising the pediatrician to assist in making preliminary decisions. The presence of a knowledge base according to the rules in the form «If ..., then ...» allows to reduce the response time of the system to the user's request.

A built-in pediatrician electronic pediatric module containing information about infants, their vaccinations and automatically generates a child's medical record. The module automates the process of workflow, reduces the time the doctor works with papers. Also, the doctor receives full information about the patient in $24 / 7$ format.

An additional advantage is the price of the software product, which, when implemented, should pay off in 1 year.

Weaknesses. The weakness of the created software product is the initial stage of the implementation of the system, which will require electronic filling of patient data, but it will pay off in the process of operation.

Opportunities. In the future, this system allows to add modules for all doctors of the children's polyclinic. The program is implemented taking this opportunity into account. The patient's medical history will be available to every specialist. The prospect of forming an electronic record in the form of tables will allow to reduce the time costs when transferring children's records to adult record files.

Threats. Threats that will have negative consequences for the decision support system of a pediatrician can be considered:

- inadequate health financing for the purchase of the program;

- training costs for clinic staff;

- the need to introduce into the personnel of the clinic a specialist who will be responsible for the maintenance of the software product;

- initial time spent filling the patient database.

In the world there are a large number of medical diagnostic systems devoted to the study of a certain number of diseases (one or several). Their use saves time, and in the future and means with their wide implementation. The MYCIN expert system can be considered analogous to the software product [17], which has a simple and logical interface and the expert system of medical diagnostics «Consilium» [18], through which the diagnosis and treatment of certain classes of infectious diseases of the blood occurs.

These systems are designed for American healthcare, have received state funding and are introduced in many clinics. The developed software product takes into account the advantages of analogues on the market, but it has cheaper cost and has advantages in ease of use, which is necessary for modern doctors.

\section{Conclusions}

1. The research of the methods of DSS design by a pediatrician when examining the existing solutions of the problem is carried out. Methods for applying the potential of artificial intelligence in medicine in the form of fuzzy rules or conducting diagnostics on the basis of Bayesian networks are considered. Intellectual computing tools in the form of expert systems based on rules and fuzzy logic, applied to neural networks and genetic algorithms performed in medical diagnostics are considered.

To develop a decision support system for a pediatrician, a method to build a knowledge base on the basis of logical rules «If ..., then ...» was chosen.

2. The logical links of the nodes are described at the stage of designing the decision support system of a pediatrician with the help of Case tools. The contextual diagram of the pediatrician decision support system reflecting the main activities of the children's hospital requiring automation is given. The study of technological processes provided an opportunity to obtain information on the openness and closure of workflow cycles.

3. The weight coefficients for the rules of the knowledge base of the system that correspond to the sets of children's symptoms of disease are described. These rules form the knowledge base of the software product. The form of the rules «If ..., then ...» is selected in accordance with the considered methods of DSS design.

4. The structural scheme of the work of DSS by a pediatrician and the main results of work as an example of the description of the software implementation of a pediatrician diagnostic DSS are given. The created system has 5 main modules: information protection, primary reception, repeated reception, database, knowledge base. Interaction between the modules is carried out using the main menu of the program and internal interaction from the knowledge base.

5. The calculation of economic efficiency from the DSS implementation by a pediatrician is performed. The system cost is to be recouped within 1 year.

\section{References}

1. Building a Better Delivery System A New Engineering/ ed. by Reid P. P., Compton W. D., Grossman J. H., Fanjiang G. Washington: National Academies Press, 2005. 276 p. doi:10.17226/ 11378

2. Kitporntheranunt M., Wiriyasuttiwong W. Development of a Medical Expert System for the Diagnosis of Ectopic Pregnancy // Journal of the Medical Association of Thailand. 2010. Vol. 93, No. 2. P. 43-49.

3. Milho I., Fred A. A User-Friendly Development Tool for Medical Diagnosis Based on Bayesian Networks // Enterprise Information Systems II. Dordrecht: Springer, 2001. P. 113-118. doi:10.1007/978-94-017-1427-3_16

4. Reddy K. Developing Reliable $\bar{C}$ linical Diagnosis Support System. 2009. 56 p. URL: http://www.kiranreddys.com/articles/ clinicaldiagnosissupportsystems.pdf

5. Kovalchuk O. Ya., Ivanytskyi R. I. Ekspertni systemy v medytsyni. Ternopil: Ternopilska derzhavna medychna akademiia imeni I. Ya. Horbachevskoho, 2004. URL: http://studcon.org/ perspektyvy-rozvytku-medychnyh-informaciynyh-system

6. Musabekova L. M., Irsimbetova A. I. Overview of methods and tools for the expert systems in medicine // Eurasian Economic Club of Scientists Association. February 20, 2017. URL: http://group-global.org/en/node/58678

7. A knowledge-based system for tutoring bronchial asthma diagnosis: proceedings / Prasad B. et al. // Second Annual IEEE Symposium on Computer-Based Medical Systems. 1989. doi:10.1109/ cbmsys.1989.47356 
8. Bursuk E., Ozkan M., Ilerigelen B. A medical expert system in cardiological diseases: proceedings // IEEE Engineering in Medicine and Biology 21st Annual Conference and the 1999 Annual Fall Meeting of the Biomedical Engineering Society. 1999. doi:10.1109/iembs.1999.804376

9. Expert system for early diagnosis of eye diseases infecting the Malaysian population: proceedings / Ibrahim F. et al. // IEEE Region 10 International Conference on Electrical and Electronic Technology. TENCON 2001. 2001. doi:10.1109/tencon.2001.949629

10. Gebremariam S. A Self Learning Knowledge Based System for Diagnosis and Treatment of Diabetes: Master's thesis. Ethiopia: Addis Ababa University. URL: http://etd.aau.edu.et/handle/ $123456789 / 8770$

11. Fatima B., Amine C. M. A Neuro-Fuzzy Inference Model for Breast Cancer Recognition // International Journal of Computer Science and Information Technology. 2012. Vol. 4, No. 5. P. 163-173. doi:10.5121/ijcsit.2012.4513

12. Singla J., Grover D., Bhandari A. Medical Expert Systems for Diagnosis of Various Diseases // International Journal of Computer Applications. 2014. Vol. 93, No. 7. P. 36-43. doi:10.5120/16230-5717

13. SushilSikchi S., Sikchi S., Ali M. S. Artificial Intelligence in Medical Diagnosis // International Journal of Applied Engineering
Research. 2012. Vol. 7, No. 11. URL: https://pdfs.semanticscholar.org/5bf4/2fe6806ac76065dea9db434c0f8acb5034ef.pdf

14. Medical Diagnosis: Are Artificial Intelligence Systems Able to Diagnose the Underlying Causes of Specific Headaches? proceedings / Farrugia A. et al. // Developments in eSystems Engineering. 2013. doi:10.1109/dese.2013.72

15. Veres O. M. Otsiniuvannia proektu systemy pidtrymky pryiniattia rishen // Visnyk Natsionalnoho universytetu «Lvivska politekhnika». Informatsiini systemy ta merezhi. 2010. Vol. 673. P. 69-77.

16. Oksamytna L. P., Kravchenko O. V. Rozrobka avtomatyzovanoi systemy obliku medychnykh doslidzhen // Visnyk Cherkaskoho tekhnolohichnoho universytetu. Seriia: Tekhnichni nauky. 2016. Vol. 4. P. 46-52.

17. Ekspertna systema MYCIN. URL: http://www.aiportal.ru/articles/expert-systems/expert-systems.html

18. Skryninhovi kompiuterni diahnostychni systemy. URL: http:/ pdnr.ru/d155912.html

Kravchenko Olga, PhD, Associate Professor, Department of In formation Technologies of Designing, Cherkasy State Technological University, Ukraine, e-mail: kravchenko_ov@ukr.net,ORCID: https:/ orcid.org/0000-0002-9669-2579

\section{Grigorovskiy P., Terentyev $\mathbf{0}$., Mikautadze $\mathbf{R}$. \\ DEVELOPMENT OF THE TECHNIOUE OF EXPERT ASSESSMENT IN THE DIAGNOSIS OF THE TECHNICAL CONDITION OF BUILDINGS}

Об'єктом дослідження є інформачійні методи та технологї діагностики будівель з використанням інструментарію теорії нечітких множин. Одним з найбільи проблемних місць є відсутність системи інтелектуальних методів діагностування на базі накопичених знань експертів і поточних відомостей про стан будівель. В ході дослідження використовувалися експертні оцінки обстеження технічного стану об'єктів, як основи для прогнозування їх надійної експлуатаиї. Отримано методику експертного оцінювання при обстеженні технічного стану будівель. Запропонована методика має структуру, яка передбачає формування ознак пошкоджень через ранжування, формування експертної групи, формування правил роботи експертної групи, оцінювання ступеню узгоженості думок експертів, кількісне оцінювання ознак пошкоджень. При такому підході з'являється можливість отримання обгрунтованих результатів про наявність та ступінь пошкоджень та можливість співставлення результатів із початковими, що характеризують раніше проведені обстеження технічного стану. Запропонований підхід сприяє визначеності при розпізнаванні станів конструкиій будівель в умовах обмеженості статистичних даних з інструментальних обстежень та неточності інформації, яка грунтується на директивних методах обстежень. У порівнянні з імовірнісними підходами та методами теорії нечітких множин розглянутий підхід використовує теорію вимірювань та математичної статистики та додає впевненості експерту при обтрунтуванні необхідного оцінювання стану конструкцій. У розробленій методииі ступень та глибина експертного оцінювання конструкиій будівлі з метою приведення усієі системи в нормальний технічний стан проводиться через інтуїтивно-логічний аналіз проблем з якісним та кількісним оцінюванням суджень i формальним обробленням результатів. Забезпечується можливість вирішувати завдання оцінювання в умовах відсутності частини важливої інформації.

Ключові слова: діагностика технічного стану будівель, комп'ютеризація методів діагностики, експертне оцінювання.

\section{Introduction}

Forecasting of the deterioration of the building and determining the timing of repairs is a complex multifactorial task. In connection with the presence in the building of a large number of different in strength and durability of structures and materials, it is difficult to predict the service life as a combination of the service life of each element separately. Supervision of the object, reduced or operated, is designed to obtain information about its 